\title{
Quantitative Real-Time Polymerase Chain Reaction for Bacterial Enumeration and Allelic Discrimination to Differentiate Xanthomonas Strains on Citrus
}

\author{
J. Cubero and J. H. Graham
}

First and second authors: University of Florida, Citrus Research and Education Center, Department of Soil and Water Science, 700 Experiment Station Road, Lake Alfred 33850.

Current address of J. Cubero: Instituto Nacional de Investigación y Tecnología Agraria y Alimentaria (INIA). Ctra. De La Coruña KM 7,5. 28040 Madrid, Spain.

Accepted for publication 22 July 2005.

\begin{abstract}
Cubero, J., and Graham, J. H. 2005. Quantitative real-time polymerase chain reaction for bacterial enumeration and allelic discrimination to differentiate Xanthomonas strains on citrus. Phytopathology 95:13331340.

Quantitative real-time polymerase chain reaction (QRT-PCR) was developed for identification and enumeration of bacteria in citrus plant samples infected with Xanthomonas axonopodis pvs. citri and citrumelo, the cause of citrus bacterial canker (CBC) and citrus bacterial spot (CBS), respectively. Three sets of primers based on the pathogenicity gene (pth) in $X$. axonopodis pv. citri, a ribosomal gene in $X$. axonopodis pv. citru$m e l o$, and the leucine-responsive regulatory protein ( $l r p)$ in both pathovars were combined with TaqMan probes and applied for specific strain

plant samples obtained with the three primer-probe combinations were congruent with colony counts on plates of semiselective medium in most of the cases. However, apparent overestimation of bacterial cells by QRTPCR indicated the presence of nonculturable or nonviable cells in some samples. In addition to quantification, the lrp primers and probes permitted differentiation by allelic discrimination of Xanthomonas strains infecting citrus tissues. This technique is based on the utilization of two probes that detect a single nucleotide difference in the target sequence between different strains and was validated with a collection of cultured Xanthomonas strains as well as tissue with CBC and CBS lesions. Allelic discrimination is demonstrated to be a more specific and sensitive protocol than previously developed PCR-based methods for strain identification and quantification.
\end{abstract} detection and quantification. Calibration curves for bacterial abundance in
Two bacterial diseases, citrus bacterial canker (CBC) and citrus bacterial spot (CBS), caused by three Xanthomonas pathovars are currently affecting citrus in Florida and other subtropical areas $(3,11,14-16,36)$. CBC is caused by Xanthomonas axonopodis pv. citri that produces type A citrus canker, and by $X$. axonopodis pv. aurantifolii that causes types B and C citrus canker (36). CBS is caused by a diverse group of strains classified as $X$. axonopodis pv. citrumelo (15). Although both CBC and CBS are caused by pathovars of $X$. axonopodis, the diseases and bacterial strains are clearly different (16). CBC is a serious disease that produces erumpent, corky lesions on leaves, stems, and fruit; CBS produces flat, necrotic spots on leaves of nursery trees in Florida (16). CBC is a particular threat for citrus areas because international quarantine regulations disrupt the trade of fresh citrus fruit $(16,36)$, whereas CBS no longer is regulated (16). Pathovars citri and citrumelo, as well as pathovar aurantifolii, can be differentiated using molecular and host range analyses $(4,6,10,15)$. Recently, two subtypes of $\mathrm{CBC}, \mathrm{A}^{*}$ and $\mathrm{A}^{\mathrm{w}}$, were recognized as distinct from the A type $(37,38,41)$. Both subtypes have narrow host ranges that so far include Mexican or Key Lime (Citrus aurantifolia) and Alemow (C. macrophylla). The A* strain from Southwest Asia and the $\mathrm{A}^{\mathrm{w}}$ strain, which has been described from a very restricted area on the east coast of Florida, are closely related and show only minor genetic differences from the A strain, which has a wide host range (4). Both $\mathrm{A}^{\mathrm{w}}$ and $\mathrm{A}^{*}$ coincide with the typical $\mathrm{A}$

Corresponding author: J. H. Graham; E-mail address: jhg@ @rec.ifas.ufl.edu

DOI: 10.1094/PHYTO-95-1333

(C) 2005 The American Phytopathological Society strain in those areas $(16,31,37,38)$. Discrimination of Xanthomonas strains responsible for a specific outbreak is a fundamental issue in the eradication of CBC because an outbreak of restricted host range $A^{w}$ or $A^{*}$ strains involves eradication of only the few susceptible citrus species, whereas detection of the A strain means that all citrus hosts in the surrounding area must be removed (38).

Recent advances in diagnosis of $\mathrm{CBC}$ have been made through the application of polymerase chain reaction (PCR) protocols and primers designed for more specific and accurate bacterial identification and detection $(4,7,18,19,27,30)$. This includes development of a PCR quantification method based on the use of a mimic plasmid in a competitive PCR reaction (quantitative competitive [QC]-PCR) to enumerate $X$. axonopodis pv. citri bacteria in citrus tissues (7). In addition to the use of agarose gels and accurate imaging systems, a unique plasmid construction is necessary for each of the primer sets utilized, which reduces QC-PCR applicability (7). Quantitative real-time (QRT)-PCR overcomes these limitations by using the point in time when amplification of the target is first detected to estimate bacterial concentration $(9,28)$. RT-PCR is a detection system that measures fluorescence in the PCR reaction after each cycle $(9,12,21,28)$. Fluorescence can be generated by nonspecific dyes such as SYBR green that binds to double-stranded DNA or by fluorogenic probes $(9,12,24,33)$. With fluorogenic probes, TaqMan technology exploits the $5^{\prime} \rightarrow 3^{\prime}$ nuclease activity of $T a q$ polymerase. During amplification, a specific DNA probe conjugated with a reporter and a quencher dye hybridizes with the target sequence and is degraded by Taq polymerase. After degradation, reporter and quencher are separated, resulting in emission of a fluorescent signal of which the accumulation is monitored during the consecutive PCR cycles. 
The cycle at which the fluorescent signal exceeds a certain background fluorescence level, referred to as the threshold cycle $(\mathrm{Ct})$, is directly proportional to the amount of the target DNA present in the sample (12).

The initial step was to develop QRT-PCR-based methods for quantifying $X$. axonopodis pvs. citri and citrumelo, the latter being of importance for studies on survival and epidemiology as a model for CBC without quarantine limitations. In addition, PCR products generated by the leucine-responsive regulatory protein (lrp) primers were tested not only for bacterial detection and quantification but also for identification of Xanthomonas strains using allelic discrimination with TaqMan minor groove binder (MGB) probes $(1,23)$, where the difference in fluorescence from the respective probe before and after the RT-PCR run identifies the presence of each strain. Quantification and strain discrimination are then possible by the use of a single RT-PCR reaction, followed by a brief post-PCR step to discriminate the alleles.

\section{MATERIALS AND METHODS}

Bacterial strains and DNA isolation. Nineteen Xanthomonas strains were used in this study (Table 1). Strains were grown on nutrient agar plates for $48 \mathrm{~h}$ and bacterial cells were scraped from the plates and suspended in water. All CBC-producing Xanthomonas suspensions were heated to kill the bacteria to comply with quarantine regulations. DNA was extracted from bacterial cells with a single phenol-chloroform-isoamyl-alcohol step, precipitated in ethanol, resuspended in ultrapure water, and stored at $-20^{\circ} \mathrm{C}(35)$.

Plant DNA extraction. DNA from plant material was extracted using a protocol previously described $(7,8)$. Samples were comminuted with a sterile scalpel in sterile water at a proportion of $10 \mathrm{mg}$ of plant tissue per $1 \mathrm{ml}$ of sterile water. They were centri-

TABLE 1. Strains of Xanthomonas axonopodis pvs. citri and citrumelo used to evaluate quantitative real-time polymerase chain reaction and allelic discrimination protocols ${ }^{\mathrm{a}}$

\begin{tabular}{lll}
\hline Taxon, CBC type & \multicolumn{1}{c}{ Strain } & \multicolumn{1}{c}{ Origin } \\
\hline $\begin{array}{lll}\text { X. axonopodis pv. citrumelo } \\
\text { CBS }\end{array}$ & X100-190, X01-42, X00-139, F1 & Florida \\
X. axonopodis pv. citri & X00-1296, X01-1048, X01-31, & \\
A & MI, MA & Florida \\
& JK20.3 & Thailand \\
A & JJ223-2 & Philippines \\
A & X63 & Japan \\
A & X205 & Oman \\
$A^{*}$ & X406 & Iran \\
$A^{*}$ & X322 & Saudi Arabia \\
$A^{*}$ & X03-1004, X0058, X01-32 & Florida \\
A $^{\text {w }}$ &
\end{tabular}

${ }^{\mathrm{a}} \mathrm{CBC}=$ citrus bacterial canker; $\mathrm{CBS}=$ citrus bacterial spot strain. fuged at $13,000 \mathrm{rpm}$ for $10 \mathrm{~min}$ and pellets resuspended in extraction buffer (200 mM Tris- $\mathrm{HCl}, \mathrm{pH} 7.5 ; 250 \mathrm{mM} \mathrm{NaCl}$; 25 M EDTA; $0.4 \%$ sodium dodecyl sulfate; $2 \%$ polyvinyl pyrrolidone [MW 10,000]) and shaken for $1 \mathrm{~h}$ at room temperature. After centrifugation for $1 \mathrm{~min}$ at 13,000 rpm, supernatant was mixed with an equal volume of isopropanol, sodium acetate, and Pellet Paint Coprecipitant as described by the manufacturer (Novagen, Darmstadt, Germany) (40). After a 1-h precipitation, washes with ethanol at 95 and $75 \%$ were performed. Precipitates were dried, resuspended in sterile ultrapure water, and stored at $-20^{\circ} \mathrm{C}$ until further use.

Primer and probe design and RT-PCR conditions. Oligonucleotide primers and probes were designed using ABI PRISM Primer Express software (version 2.0; Applied Biosystems, Foster City, CA) (Table 2). A set of primers (J-pth3 and J-pth4) and the corresponding TaqMan probe (J-Taqpth2) labeled at the $5^{\prime}$ end with 6-carboxyfluorescein (FAM) and at the $3^{\prime}$ end with tetramethylrhodamine were designed based on sequences of the pth gene, a major virulence gene $(2,39,43)$ used in other works specifically to detect $\mathrm{CBC}$ strains $(4,30)$. Another set of primers $(J$-RTRib16Sup and J-RTRib16SdownXC2) and TaqMan probe $(J-$ Taq16S-1) labeled as above were made based on the ribosomal DNA of $X$. axonopodis pv. citrumelo. Sequences were selected in a region specific for this bacterium assessed in a previous work (4). Finally, a set of primers (J-ADlrpU1 and J-AD1lrpU2) was designed based on the sequence of the lrp gene. This gene also has been studied extensively in a preceding work on a broad collection of Xanthomonas species, including several CBS and different types of $\mathrm{CBC}$ strains (6). One of the sequence differences in the lrp gene between strains $\mathrm{A}$ and $\mathrm{A}^{*} / \mathrm{A}^{\mathrm{w}}$ is a single nucleotide $(\mathrm{A} / \mathrm{G})$ in position 417 (accession no. AY227405 and AY227411) (6); therefore, two FAM and VIC MGB probes were designed based on this dissimilarity (Table 2). TaqMan MGB probes labeled with FAM (J-Alrpallelicl) and with the fluorescent dye VIC (J-Awlrpallelic1; PE Biosystems, Weiterstadt, Germany) were designed to hybridize with canker strains of type A and restricted host range strains $\mathrm{A}^{*}$ and $\mathrm{A}^{\mathrm{w}}$, respectively.

QRT-PCRs were carried out by adding $5 \mu \mathrm{l}$ of the template DNA to a reaction mixture containing $12.5 \mu$ of $2 \times$ PCR universal master mix (Applied Biosystems), $1 \mu \mathrm{l}$ of $10 \mu \mathrm{M}$ forward primer (J-RTpth3, J-RTRib16Sup, or J-ADlrpU1), $1 \mu \mathrm{l}$ of $10 \mu \mathrm{M}$ reverse primer (J-RTpth4, J-RTRib16SdownXC2, or J-AD1lrpU2), and $0.5 \mu \mathrm{l}$ of $10 \mu \mathrm{M}$ TaqMan probe (J-Taqpth2 or J-Taq16S-1) in a final reaction volume of $25 \mu \mathrm{l}$. Where allelic discrimination was performed, $0.5 \mu \mathrm{l}$ of each $10-\mu \mathrm{M}$ TaqMan MGB probe (J-Alrpallelicl and J-Awlrpallelicl) was added.

QRT-PCR reactions were completed in an ABI PRISM 7000 Sequence Detection System (Applied Biosystems). Amplification conditions for all the primers and probes consisted of an initial activation step of $10 \mathrm{~min}$ at $95^{\circ} \mathrm{C}$ followed by 40 cycles of $15 \mathrm{~s}$ at $95^{\circ} \mathrm{C}$ and $1 \mathrm{~min}$ at $60^{\circ} \mathrm{C}$.

TABLE 2. Primers and probes used in quantitative real-time polymerase chain reaction and allelic discrimination reactions

\begin{tabular}{|c|c|c|}
\hline Primers & Sequence $\left(5^{\prime} \rightarrow 3^{\prime}\right)$ & Target $^{\mathrm{a}}$ \\
\hline$J-R T p t h 3$ & ACCGTCCСCTACTTCAACTCAA & pth gene, universal for citrus bacterial canker strains \\
\hline$J-R T p t h 4$ & CGCACCTCGAACGATTGC & \\
\hline J-RTRib16Sup & GTGACGTAGCGAGCGTTTGA & Ribosomal sequence, specific for Xanthomonas axonopodis pv. citrumelo \\
\hline$J-A D l r p U 1$ & GCGTCCTACCGCAAGTTGC & lrp gene, universal in Xanthomonas spp. \\
\hline$J-A D 1 l i r p U 2$ & CCTTGACCTCTTCCATCACGAT & \\
\hline Probes & & \\
\hline$J-T a q p t h 2^{\mathrm{b}}$ & fam-ATGCGCCCAGCCCAACGC-tamra & pth gene, universal for citrus bacterial canker strains \\
\hline$J$-Awlrpallelic $1^{\mathrm{c}}$ & vic-AGCTCTTGGACTCAC-mgbnfq & lrp gene, specific for restricted host range strains of $X$. axonopodis pv. citri \\
\hline
\end{tabular}


QRT-PCR standard curves. To obtain standard curves for QRT-PCR that relate bacterial concentration to a $\mathrm{Ct}$, suspensions of the MI strain of $X$. axonopodis pv. citri and the F1 strain of $X$. axonopodis pv. citrumelo grown overnight in nutrient broth were added to ground grapefruit leaves free of any disease symptoms. Plant extracts were prepared by comminuting $10 \mathrm{mg}$ of leaf tissue per $1 \mathrm{ml}$ of sterile water, and adjusted to 10 -fold bacterial concentrations in a range of 1 to $10^{8} \mathrm{CFU} / \mathrm{ml}$. DNA extractions were performed as described above for plant material. Serial dilutions of plant extracts amended with $X$. axonopodis pvs. citri or citrumelo also were plated on medium amended with kasugamycin, cephalexin, and Bravo (KCB) (15). After $72 \mathrm{~h}$, colonies were counted to confirm the initial concentrations of bacteria. Each sample used to calculate the standard curve was amplified twice and, to control the consistency of the DNA recovery from leaves, two independent bacterial dilutions series were used for the pth primers standard curve. No significant differences between extractions were found; therefore, just one extraction series was used for the ribosomal and lrp standard curves.

Allelic discrimination. Allelic discrimination was performed on PCR products. After PCR amplification using the lrp set of primers and probes, the $\Delta \mathrm{R}$ (change in fluorescence) for each dye was measured and an $x-y$ scatterplot used to identify the specific genotypes based on their location on the graph. QRT-PCR reaction and post-PCR analysis were carried out in an ABI PRISM 7000 Sequence Detection System (Applied Biosystems). Allelic discrimination was performed using PCR products obtained after amplification of pure bacterial cultures as well as amplification from infected plant material.

Plant samples analyzed. DNA from eight samples of artificially and naturally infected plants (Table 3) was extracted and amplified by QRT-PCR as described above. Artificially infected plants were inoculated by pressure infiltration with a syringe without needle and analyzed after 2 months when symptoms were shown. Ribosomal and pth primers and probes were used for detection of CBS and CBC, respectively. In both cases, DNA also was amplified with lrp primers using the probes for allelic discrimination to check the fluorescence in QRT-PCR. Each sample was amplified twice and results presented as an average.

Statistical analysis. All statistic analyses were performed using Statgraphics Plus for Windows 4.1 (Statistical Graphics, Rockville, MD). Linear regression analysis was performed to calculate equations for calibration curves that relate bacterial concentration and $\mathrm{Ct}$. A comparison between calibration curves obtained from the two independent bacterial dilution series used to test the $p$ th primer-probe combination was performed. Data from the plant samples were subjected to analysis of variance and the means separated by Student-Newman-Keuls multiple range test.

\section{RESULTS}

Calibration curves. The calibration curve obtained using primers and a TaqMan probe based on the pth gene to detect and

TABLE 3. Plant material used in quantitative real-time polymerase chain reaction and allelic discrimination

\begin{tabular}{llc}
\hline Sample & \multicolumn{1}{c}{ Plant } & Strain inoculated \\
\hline N2 & Grapefruit & $\mathrm{F}^{\mathrm{a}}$ \\
N3 & Grapefruit & $\mathrm{F} 1$ \\
O1 & Grapefruit & $\mathrm{F} 1$ \\
O2 & Grapefruit & $\mathrm{F} 1$ \\
B1 & Sweet orange & $\mathrm{MI}^{\mathrm{b}}$ \\
Z1 & Sweet orange & $\mathrm{MI}^{\mathrm{N}}$ \\
F15 & Sweet orange & $\mathrm{NA}^{\mathrm{c}}$ \\
F19 & Mexican-lime & $\mathrm{NA}$ \\
\hline
\end{tabular}

${ }^{a}$ Xanthomonas axonopodis pv. citrumelo.

${ }^{\mathrm{b}} X$. axonopodis pv. citri.

${ }^{\mathrm{c}}$ Not applicable: naturally infected sample. quantify $X$. axonopodis pv. citri is shown in Figure 1. Threshold fluorescence was set at 0.2 and the baseline was selected from cycle 1 to 13 because exponential amplification from sample $10^{7}$ bacteria/ml was first detected at approximately cycle 15 . Plotting the cycle number versus the log-concentration of the bacteria gave a straight-line regression plot with a correlation coefficient of $r=-0.993$. Data from two independent bacterial dilution series were used to calculate the calibration curve. When the two series were compared, the two regression lines did not differ statistically $\left(P<0.0001\right.$, adjusted $\left.R^{2}=0.9847\right)$. Amplification efficiency $\left(10^{-(1 / \text { slope })}\right)(34)$ for the $p$ th primer-probe combination was 2 , which indicated that 1 to $10^{7}$ bacteria $/ \mathrm{ml}$ could be detected and quantified accurately. Therefore, on leaf tissue the sensitivity was $0.1 \mathrm{bacteria} / \mathrm{mg}$ of tissue.

The calibration curve obtained using primers and a TaqMan probe based on a ribosomal sequence to detect $X$. axonopodis pv. citrumelo is shown in Figure 2. Threshold fluorescence was set at 0.4 and the baseline from cycle 1 to 16 . The regression had a correlation coefficient of $r=-0.998$ and amplification efficiency of 1.98 .

Calibration curves obtained using primers and TaqMan for the lrp gene and FAM as the fluorescent marker to detect and quantify $X$. axonopodis pvs. citri and citrumelo are shown in Figure $3 \mathrm{~A}$ and $\mathrm{B}$, respectively. Threshold fluorescence was set at 0.2 and baseline from cycle 1 to 15 . Correlation coefficients for the calibration curves were $r=-0.990$ and -0.999 for pvs. citri

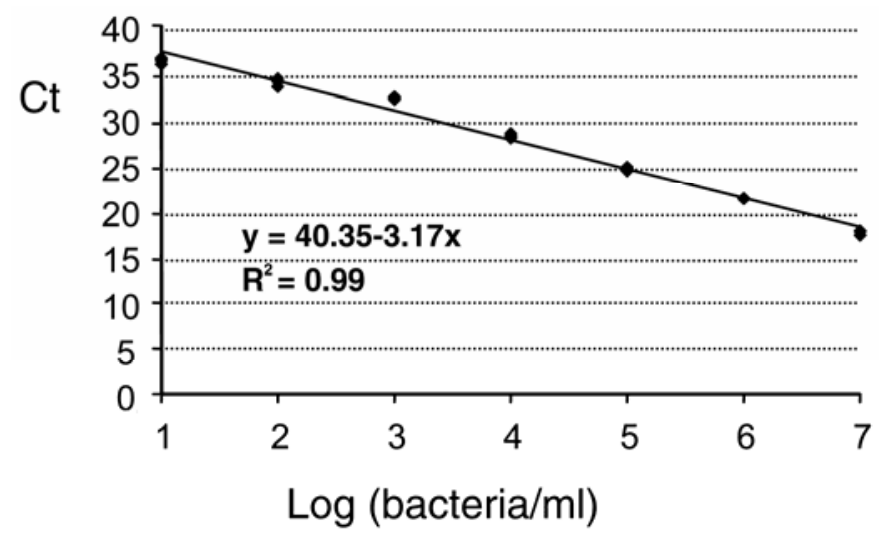

Fig. 1. Calibration curve of log-bacterial concentration (strain MI of Xanthomonas axonopodis pv. citri) versus threshold cycle $(\mathrm{Ct})$ after real-time polymerase chain reaction using primers and TaqMan probe for a pth sequence. Baseline from cycle 1 to 13 and threshold fluorescence of 0.2 were selected. Also shown is the linear regression equation with its $R^{2}$.

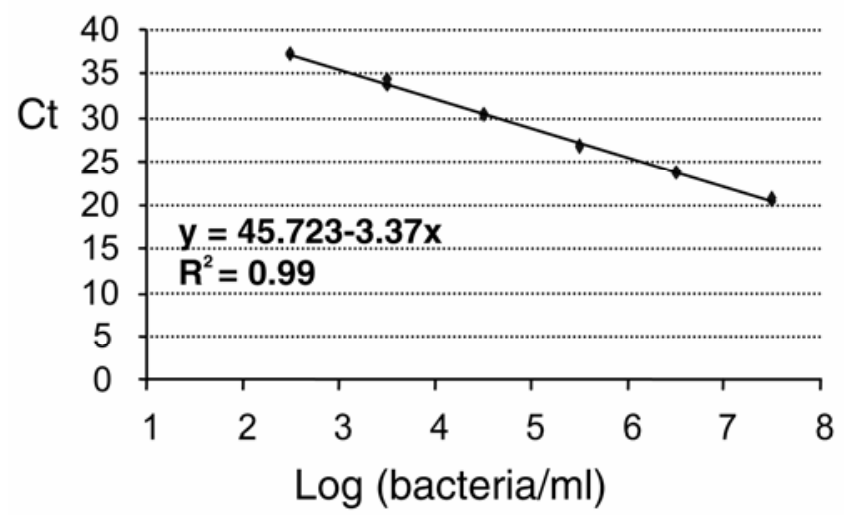

Fig. 2. Calibration curve of log-bacterial concentration (strain F1 of Xanthomonas axonopodis pv. citrumelo) versus threshold cycle $(\mathrm{Ct})$ after real-time polymerase chain reaction using primers and TaqMan probe for a ribosomal sequence. Baseline from cycle 1 to 16 and threshold fluorescence of 0.4 were selected. Also shown is the linear regression equation with its $R^{2}$. 
and citrumelo, respectively, and both amplification efficiencies equaled to 2 .

The calibration curves obtained using primers and the TaqMan MGB probe for the lrp gene with VIC as the fluorescent marker to detect and quantify $X$. axonopodis pvs. citri and citrumelo are shown in Figure 4A and B, respectively. Threshold fluorescence was set at 0.2 and baseline from cycle 1 to 15 . Correlation coefficients for the calibration curves were $r=-0.998$ and -0.994 for pvs. citri and citrumelo, respectively, and the amplification efficiencies were 1.87 and 1.88 .

Estimation of bacterial abundance in plant samples. Two leaf samples of inoculated sweet orange (B1 and Z1) (Table 3) were analyzed to detect and quantify $X$. axonopodis pv. citri using three primer-probe combinations (Fig. 5). In sample B1, bacterial abundances $\left(10^{\text {mean } \pm \text { standard deviation }}\right)$ of $10^{7.7 \pm 0.0}, 10^{7.5 \pm 0.1}$, and $10^{7.5 \pm 0.1}$ bacteria/ml were estimated by QRT-PCR using the $p$ th primers and probe, and the lrp primers using FAM and VIC as fluorescent markers, respectively. By colony counts, bacterial abundance was estimated as $10^{7.4 \pm 0.6} \mathrm{bacteria} / \mathrm{ml}$. No significant differences were shown among any of the detection methods used $(P<0.8762)$. However, significant differences were observed between colony counts and each of the QRT-PCR methods used in sample $\mathrm{Z} 1(P<0.0001)$. Bacterial abundances of $10^{7.9 \pm 0.0}$, $10^{7.7 \pm 0.1}$, and $10^{7.7 \pm 0.1}$ bacteria/ml were estimated by QRT-PCR with pth primer-probe and lrp primers using FAM or VIC as fluorescent markers, respectively, whereas $10^{6.4 \pm 0.1}$ bacteria/ml was estimated by colony counts.
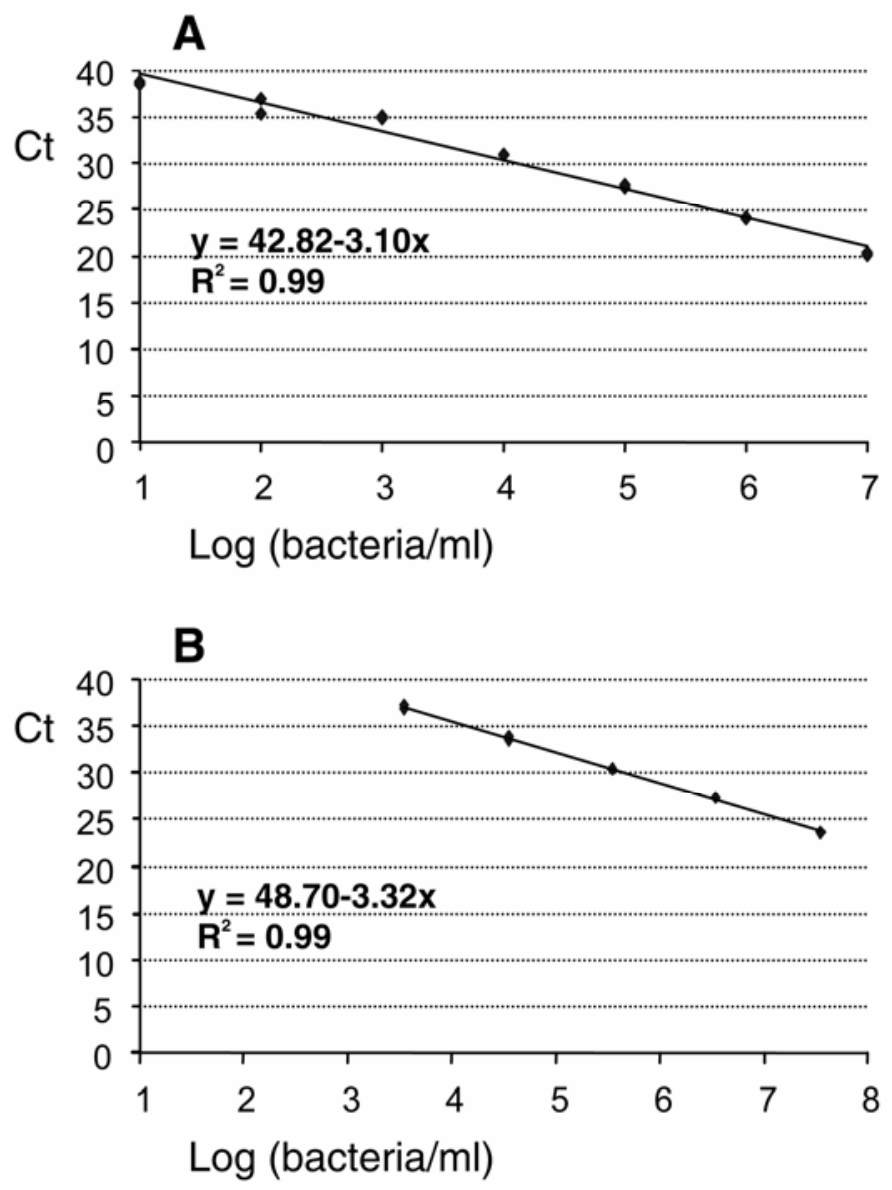

Fig. 3. Calibration curves of log-bacterial concentration of Xanthomonas axonopodis pvs. A, citri (strain MI) and B, citrumelo (strain F1) versus threshold cycle $(\mathrm{Ct})$ after real-time polymerase chain reaction using primers and TaqMan minor groove binder probe for a leucine-responsive regulatory protein sequence measuring FAM fluorescence. Baseline from cycle 1 to 15 and threshold fluorescence of 0.2 were selected. Also shown is the linear regression equation with its $R^{2}$.
Analogous results were obtained for CBS samples using primers and probes from the ribosomal and lrp regions (Fig. 6). Four leaf samples of grapefruit (N2, N3, O1, and O2) (Table 3) were analyzed and, in $\mathrm{N} 2$ and $\mathrm{N} 3$, significant differences in bacterial enumeration were obtained between QRT-PCR and plate counts $(P<0.0069$ and 0.0002 for $\mathrm{N} 2$ and N3, respectively). Bacterial abundance in sample N3 was estimated to be between $10^{7.5}$ and $10^{7.8}$ bacteria/ml by QRT-PCR and $10^{6.5 \pm 0.2}$ bacteria $/ \mathrm{ml}$ by colony counts. Similar results were obtained in sample N2, although here differences were lower: $10^{7.4}$ to $10^{7.9}$ bacteria/ml by QRT-PCR and $10^{7.0 \pm 0.3}$ bacteria/ml by colony counts. In samples $\mathrm{O} 1$ and $\mathrm{O} 2$, no significant differences were found between the detection methods used $(P<0.0699$ and 0.2451 for $\mathrm{O} 1$ and $\mathrm{O} 2$, respectively). A range of $10^{7.0}$ to $10^{7.6}$ bacteria/ml was detected in $\mathrm{O} 1$ and a range from $10^{6.8}$ to $10^{7.3}$ bacteria/ml in $\mathrm{O} 2$.

Allelic discrimination. Three clusters of points corresponding to $X$. axonopodis pv. citri type $\mathrm{A}$ and type $\mathrm{A}^{*} / \mathrm{A}^{\mathrm{w}}$ and $X$. axonopodis pv. citrumelo are shown in the graphic reporting the fluorescence due to each dye (Fig. 7). Where most of the fluorescence in a sample was from FAM, the bacterium was expected to be of a common A strain. Where most of the fluorescence was from VIC, the bacterium was considered to be of a limited host range strain, $\mathrm{A}^{*}$ or $\mathrm{A}^{\mathrm{w}}$. Where relatively poor fluorescence came from both dyes, the bacteria was considered to be $X$. axonopodis pv. citrumelo. All the strains were included in the corresponding group according to strains characteristics described elsewhere (4).

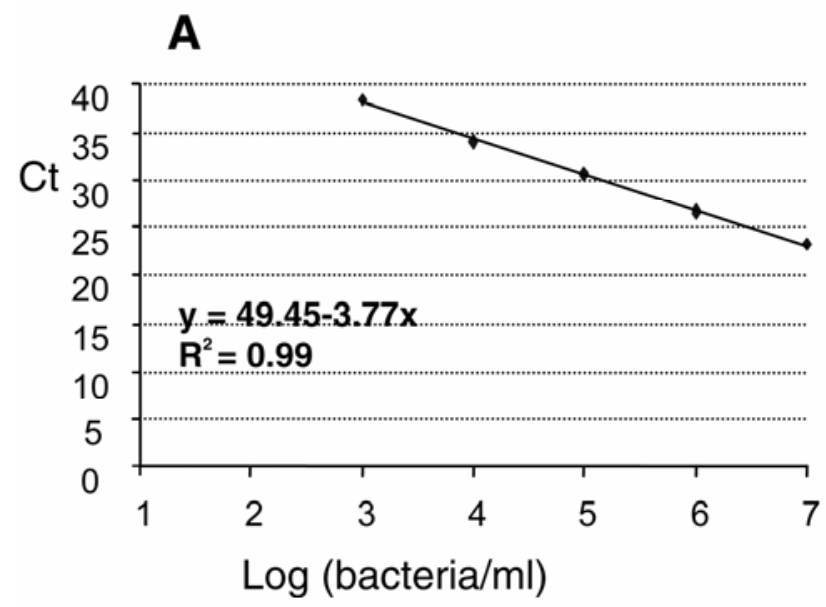

B

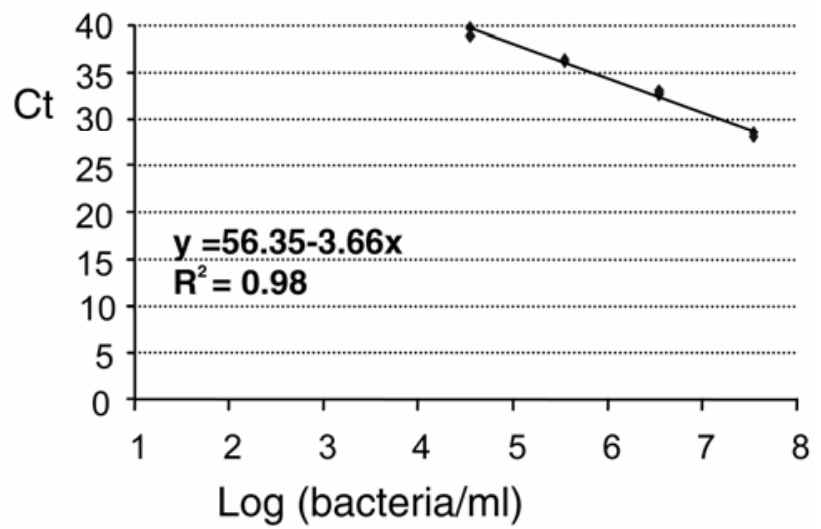

Fig. 4. Calibration curve of log-bacterial concentration of Xanthomonas axonopodis pvs. A, citri (strain MI) and B, citrumelo (strain F1) versus threshold cycle $(\mathrm{Ct})$ after real-time polymerase chain reaction using primers and TaqMan minor groove binder probe for a leucine-responsive regulatory protein sequence measuring VIC fluorescence. Baseline from cycle 1 to 15 and threshold fluorescence of 0.2 were selected. Also shown is the linear regression equation with its $R^{2}$. 
Genotyping by the allelic discrimination method described also was possible with DNA isolated from plant material, as shown in Figure 8. Again, three groups of points were differentiated in the scatter plot (Fig. 8). These three groups corresponded with the three groups of Xanthomonas strains tested. Each group represented the analysis of DNA from a pure bacterial culture and DNA from an infected plant. O1, a CBS-infected plant sample, appeared on the plot close to X00-139, an X. axonopodis pv. citrumelo strain; F15, a CBC-A-infected plant sample, was next to JK20.3, an X. axonopodis pv. citri type A strain; and F19, a CBC-A ${ }^{\mathrm{w}}$-infected plant sample, was close to X0058, a strain of $X$. axonopodis pv. citri type $\mathrm{A}^{\mathrm{w}}$.

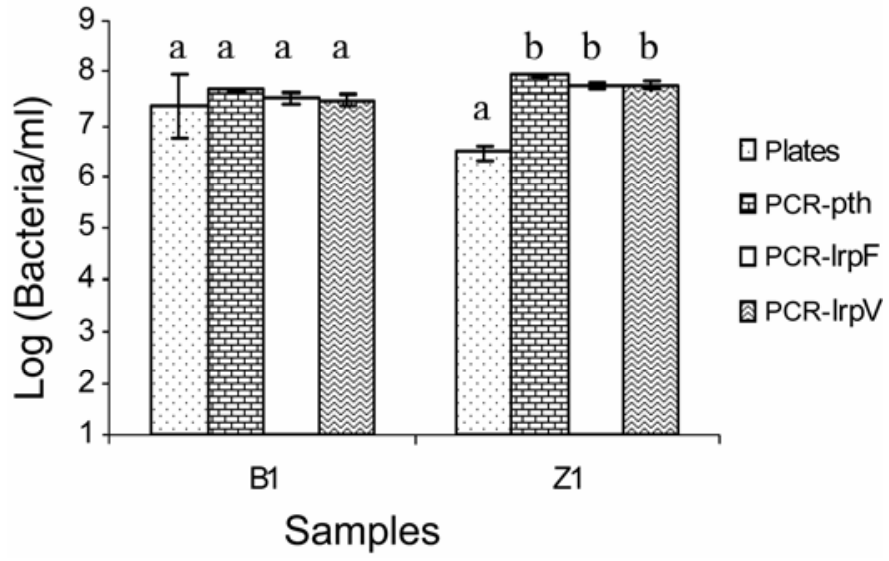

Fig. 5. Xanthomonas axonopodis pv. citri quantification on inoculated plant material described in Table 3. Methods used for quantification were colony counts on a semiselective medium (plates) and real-time polymerase chain reaction (PCR) using primer and probe for the pathogenicity (pth) gene (PCRpth) and leucine-responsive regulatory protein (lrp) primers using FAM (PCR-lrpF) or VIC (PCR-lrpV) as the fluorescent marker. The graph shows the average of two replicates for each treatment with the standard deviation (error bars) for quantitative real-time PCR reactions and six replicates for plate counting. Means with the same letter within a sample do not differ significantly according to the Student-Newman-Keuls multiple range test $(P<0.05)$.

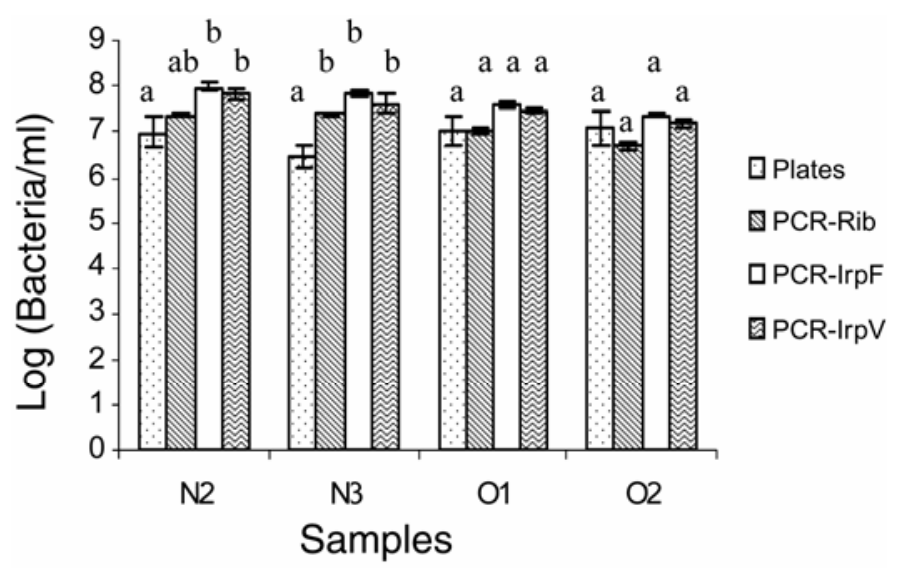

Fig. 6. Xanthomonas axonopodis pv. citrumelo quantification on inoculated plant material described in Table 3. Methods used for quantification were colony counts on a semiselective medium (plates) and real-time polymerase chain reaction (PCR) using ribosomal primers and probe (PCR-Rib) and leucine-responsive regulatory protein ( $\operatorname{lrp}$ ) primers using FAM (PCR-lrpF) or VIC (PCR-lrpV) as the fluorescent marker. The graph shows the average for two replicates for each treatment with the standard deviation (error bars) for quantitative real-time PCR reactions and six replicates for plate counting. Means with the same letter within a sample do not differ significantly according to the Student-Newman-Keuls multiple range test $(P<0.05)$.

\section{DISCUSSION}

Calibration curves were generated for $X$. axonopodis pvs. citri and citrumelo based on the assumption that the concentration of bacteria was directly related to DNA concentration. First, a calibration curve was calculated based on the $\mathrm{Ct}$ obtained after amplification using the $p t h$ primer-probe combination to quantify $X$. axonopodis pv. citri in plants. Specificity for CBC diagnosis was assured because pth is found in this pathovar but not in other bacteria belonging to the same genus attacking the same host $(4,32)$. This gene also is present in other Xanthomonas spp.; however, xanthomonads containing pth different from those causing CBC are not likely to be isolated from citrus. Indeed, primers for the pth gene were designed based on previous results obtained with $\mathrm{CBC}$ strains, including types $\mathrm{A}, \mathrm{A}^{\mathrm{w}}, \mathrm{A}^{*}, \mathrm{~B}$, and $\mathrm{C}$, and also

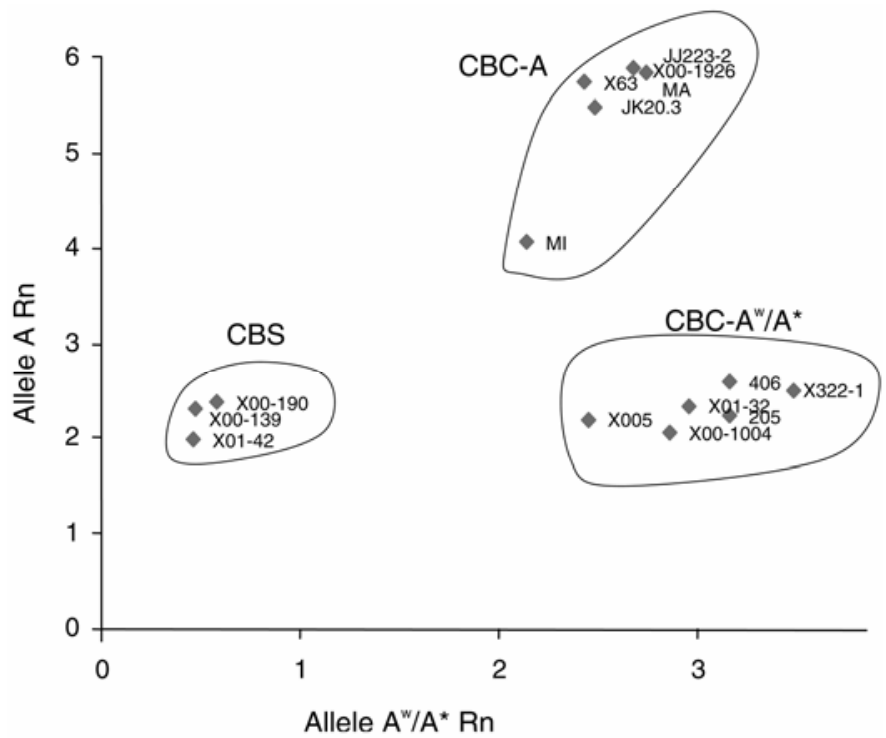

Fig. 7. Fluorescence plot for FAM versus VIC after real-time polymerase chain reaction (RT-PCR) using primers and probes for the leucine-responsive regulatory protein $(l r p)$ gene and allelic discrimination of DNA obtained from Xanthomonas spp. isolated from citrus in different world areas. $\mathrm{CBC}=$ citrus bacterial canker and CBS = citrus bacterial spot. After RT-PCR, an endpoint fluorescence reading Rn (normalized reported signal) was taken and a scatter plot of A-allele $\mathrm{Rn}$ versus $\mathrm{Aw} / \mathrm{A}^{*}$-allele $\mathrm{Rn}$ was made using sequence detection system software.

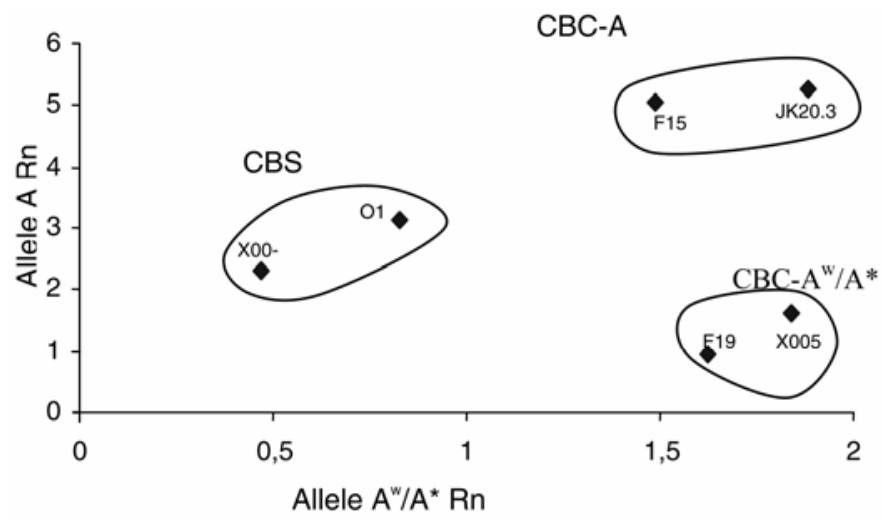

Fig. 8. Fluorescence plot for FAM versus VIC after real-time polymerase chain reaction (RT-PCR) using primers and probes for the leucine-responsive regulatory protein (lrp) gene and allelic discrimination of DNA obtained from Xanthomonas axonopodis pvs. citri (JK20.3 type A and X0058 type $\mathrm{A}^{\mathrm{w}}$ ) and citrumelo (X00-139) and from infected plant material (O1, F15, and F19). $\mathrm{CBC}=$ citrus bacterial canker and $\mathrm{CBS}=$ citrus bacterial spot. After RT-PCR, an endpoint fluorescence reading $\mathrm{Rn}$ (normalized reported signal) was taken and a scatter plot of A-allele Rn versus Aw/A*-allele $\mathrm{Rn}$ was made using sequence detection system software. 
$X$. axonopodis pv. citrumelo, a non-pth-containing strain that was used as a negative control (4). This region also has been used recently by other authors to develop specific primers for CBC diagnosis (30). Compared with other quantitative PCR methods different from RT reactions such as QC-PCR (7), the sensitivity of the PCR was improved by a factor of 100 to 1,000 for quantification of bacterial abundance. Moreover, sensitivity of the detection method was similar to SYBR green detection of doublestranded DNA amplified from the same genomic region (30). In the case of CBS, primers were designed based on the previously obtained sequence of the intergenic spacer of the ribosomal sequences (4). In this ribosomal region, specific sequences for $X$. axonopodis pv. citrumelo have been described (4). Using these primers, a standard curve was obtained showing a lower sensitivity than that obtained for $\mathrm{CBC}$ using the pth primers. This difference in primer sensitivity may be a result of the chromosomal origin of the amplified fragment or lower gene repetition. Although this set of primers is useful to detect and quantify $X$. axonopodis pv. citrumelo in inoculated plants, we cannot recommend its use for diagnosis of field samples. Variability in ribosomal sequences among Xanthomonas spp. is very low $(4,13$, 20) and specific primers for each of the pathovars within the same species are hard to obtain. Thus, quantities of $X$. axonopodis pv. citrumelo may be overestimated if other related xanthomonads are present. For example, $X$. axonopodis pv. citri may be amplified and misidentified as $X$. axonopodis pv. citrumelo by the use of these primers because of the high homology between both pathovars within this genomic region (4). The specific methodology discussed below and derived from the lrp region is more advisable for diagnosis of CBS. Calibration curves for quantification based on $l r p$ primers and two TaqMan MGB probes with FAM and VIC as the fluorescent dyes were obtained. The lrp gene is universally present in Xanthomonas spp., and variability in this gene has been used previously to determine the phylogenetic relationship among Xanthomonas spp. (6). This sequence variability has been exploited to design specific assays for diagnosis of CBS and $\mathrm{CBC}$ in this work. For CBC, the sensitivity with $\operatorname{lrp}$ primers was equivalent to that obtained with those based on pth, whereas it was lower for X. axonopodis pv. citrumelo because the MGB probes were designed for amplification of either the A strain (FAM) or the $A^{*}$ and $A^{w}$ strains (VIC). The differences of the CBS sequences resulted in less affinity of the probes for the target sequence and less efficiency of the nuclease activity of the Taq polymerase. Less nuclease activity means less separation of the fluorogenic dye from the quencher, which reduces fluorescence and, thus, sensitivity. Calibration curves generated from QRTPCR for CBC and CBS using probes labeled with the VIC fluorescence signal were less sensitive compared with FAM using the same lrp primers. This probably is due to the slightly minor affinity of the probe for the target in A strains and also may be due to less intense fluorescence of VIC. As expected, sensitivity for quantification of $X$. axonopodis pv. citri also was higher than for $X$. axonopodis pv. citrumelo because of a greater affinity of the TaqMan probes to the target sequence. In all cases, the sensitivity using lrp primers was lower compared with the pth or ribosomal primers.

The correlation coefficients of all the calibration curves indicate a relatively strong relationship between bacterial abundance and Ct in the QRT-PCR reaction. Moreover, amplification efficiencies were high over a wide range of bacterial abundance. Accuracy is demonstrated not only for QRT-PCR but also for the DNA extraction method. All standard curves were calculated using independent DNA extractions for each of the bacterial dilutions and two replicates of the QRT-PCR reaction for each sample. This means that calibration curves include variation due to the QRT-PCR as well as to the DNA extraction. In addition, the first calibration curve with $p t h$ primer-probe was obtained from two dilution series made from two different leaves; when calibra- tion curves were calculated separately from the two series, similar equations were obtained and a statistically significant similarity between the regressions was shown $(P<0.0001)$.

All protocols described here for QRT-PCR were set up initially using SYBR green; when satisfactory results were obtained, the corresponding TaqMan probe was synthesized. TaqMan technology eliminates the necessity of post-PCR evaluation because the fluorescence obtained is due only to amplification of the target sequence and not from a nonspecific product, as may occur with SYBR green protocols (30). Therefore, this method reduces the risk of false positives and increases the reliability of the PCR detection. TaqMan technology allows the use of higher primer concentrations because the formation of primer-dimers does not add to the fluorescence. Elevation of primer concentrations allows for the detection of lower concentrations of bacteria, and this is essential in samples with non-optimal PCR conditions such as field samples of leaves with old lesions.

Samples of infected plants were subjected to analysis with the different QRT-PCR protocols and compared with colonies detected on a semiselective medium. In most of the samples, colony counts in plants coincided with data obtained by QRT-PCR; however, in some cases, lower bacterial abundance was detected on culture plates. Although QRT-PCR is suitable for quantification, DNA detection does not necessarily correspond with the presence of viable cells as reported for many bacterial models, including CBC $(8,22,25,26,30)$. DNA is stable in dead cells and this implies that the number of viable bacterial cells may be overestimated by PCR, as shown in our experiments with CBS and CBC. The nonculturable fraction probably represents mainly nonviable bacteria. Viable but nonculturable fractions have been considered to be of possible importance in several bacterial species $(17,29,42)$, but their significance could not be confirmed yet in $X$. axonopodis infecting citrus trees (5). Therefore, QRT-PCR is applicable only for quantification of living bacteria in young lesions when bacterial populations are active. However, QRT-PCR may be very useful for diagnosis and bacterial quantification in cases of tolerance zero, when it is not necessary to probe viability of the pathogen. It also may be applicable for epidemiological studies under controlled conditions, but probably not for lesions of mixed age in the field. For that reason, field studies on bacterial survival require other methods as plate counts or utilization of nonstable nucleic acids such as mRNAs to confirm viability of the population.

No significant differences in quantification were observed among the primer-probe combinations in any of the samples analyzed, although they did show different sensitivities according to the standard curves. This is because bacterial concentrations in all the samples were within the sensitivity range of all the protocols tested. However, if low populations are expected, the most sensitive protocols recommended are the pth primer-probe combination for detection of $X$. axonopodis pv. citri and the ribosomal primer-probe combination for detection of $X$. axonopodis $\mathrm{pv}$. citrumelo.

Although some bacteria egressing from lesions are detectable with minor or no DNA extractions as described by other authors (30), a DNA extraction protocol should be applied in order to release DNA from bacteria inside the plant tissue. Electron (16) or confocal microscopy (unpublished data) studies indicated that a high concentration of bacterial cells remain in intercellular spaces. Amplification from these bacterial cells requires a total DNA extraction protocol like the one described above which was shown accurate enough to keep experimental variability low. In addition, DNA extraction plays an essential role in concentrating the samples in order to attain low detection thresholds.

Allelic discrimination among the three main strains of $X$. axonopodis was possible following the protocol described and by the use of controls corresponding to strains of CBS and CBC of restricted and wide host range. This PCR method is based on the 
accumulation of a fluorescence signal during the nucleolytic degradation of an internally quenched allele-specific probe. A single nucleotide difference between probes $J$-Alrpallelic 1 and $J$ Awlrpallelicl and their templates resulted in different melting temperatures. This mismatch is responsible for a reduced hybridization efficiency and consequent reduced nuclease effectiveness of the Taq polymerase. For samples containing the A strain, the FAM probe was cleaved whereas the VIC probe remained more intact and, thus, quenched. For samples containing the $\mathrm{A}^{\mathrm{w}}$ or $\mathrm{A}^{*}$ strain, the VIC probe was cleaved and more FAM probe remained intact. For X. axonopodis pv. citrumelo, lesser amounts of both probes were cleaved, with the result that the majority was quenched because of a difference of two nucleotides within the hybridization probe area.

Allelic discrimination by TaqMan technology provides an alternative to other methods to differentiate among different types of CBC strains as well as to differentiate from other Xanthomonas spp. This method is especially valuable in an eradication program such as Florida's, where more than one strain occurs in the same geographic area. These techniques allow regulators to rapidly identify strain types to determine which citrus species are to be removed, as well as to avoid mix up of $\mathrm{CBC}$ with similar diseases like CBS.

\section{ACKNOWLEDGMENTS}

This research was supported by the Florida Agricultural Experiment Station and grants from the United States Department of AgricultureAPHIS (99-8100-0560-CA) and the Florida Citrus Production Research Advisory Council (031-07P), and approved for publication as Journal Series No. R-10509. We thank X. Sun, O. Pruvost, and J. S. Hartung for kindly providing some of the cultures and plant samples used in this study; D. Bright, M. Dekkers, J. Noling, and A. Redondo for their assistance; and C. Redondo for statistical advice.

\section{LITERATURE CITED}

1. Afonina, I., Zivarts, M., Kutyavin, I., Lukhtanov, E., Gamper, H., and Meyer, R. B. 1997. Efficient priming of PCR with short oligonucleotides conjugated to a minor groove binder. Nucleic Acids Res. 25:2657-2660.

2. Brunings, A. M., and Gabriel, D. W. 2003. Xanthomonas citri: Breaking the surface. Mol. Plant Pathol. 4:141-157.

3. Civerolo, E. L. 1984. Bacterial canker disease of citrus. J. Rio Grande Val. Hortic. Soc. 37:127-145.

4. Cubero, J., and Graham, J. H. 2002. Genetic relationship among worldwide strains of Xanthomonas causing canker in citrus species and design of new primers for their identification by PCR. Appl. Environ. Microbiol. 68:1257-1264.

5. Cubero, J., and Graham, J. H. 2002. Does the viable but non-culturable state have implications for eradication of citrus canker bacterium? (Abstr.) Phytopathology 92(suppl.):S17.

6. Cubero, J., and Graham, J. H. 2004. The leucine responsive regulatory protein (lrp) gene for characterization of the relationship among Xanthomonas species. Int. J. Syst. Evol. Microbiol. 54:429-437.

7. Cubero, J., Graham, J. H., and Gottwald, T. R. 2001. Quantitative PCR method for diagnosis of citrus bacterial canker. Appl. Environ. Microbiol. 67:2849-2852.

8. Cubero, J., Martinez, M. C., Llop, P., and Lopez, M. M. 1999. A simple and efficient PCR method for the detection of Agrobacterium tumefaciens in plant tumours. J. Appl. Microbiol. 86:591-602.

9. Ding, C. M., and Cantor, C. R. 2004. Quantitative analysis of nucleic acids: the last few years of progress. J. Biochem. Mol. Biol. 37:1-10.

10. Egel, D. S., Graham, J. H., and Stall, R. E. 1991. Genomic relatedness of Xanthomonas campestris strains causing diseases of citrus. Appl. Environ. Microbiol. 57:2724-2730.

11. Gabriel, D. W., Kingsley, M. T., Hunter, J. E., and Gottwald, T. 1989. Reinstatement of Xanthomonas citri (ex Hasse) and Xanthomonas phaseoli (ex Smith) to species and reclassification of all Xanthomonas campestris pv. citri strains. Int. J. Syst. Bacteriol. 39:14-22.

12. Gibson, U. E. M., Heid, C. A., and Williams, P. M. 1996. A novel method for real time quantitative RT PCR. Genome Res. 6:995-1001.

13. Goncalves, E. R., and Rosato, Y. B. 2002. Phylogenetic analysis of Xanthomonas species based upon 16S-23S rDNA intergenic spacer sequences. Int. J. Syst. Evol. Microbiol. 52:355-361.
14. Gottwald, T. R., Hughes, G., Graham, J. H., Sun, X., and Riley, T. 2001. The citrus canker epidemic in Florida: The scientific basis of regulatory eradication policy for an invasive species. Phytopathology 91:30-34.

15. Graham, J. H., and Gottwald, T. R. 1990. Variation in aggressiveness of Xanthomonas campestris pv. citrumelo associated with citrus bacterial spot in Florida citrus nurseries. Phytopathology 80:190-196.

16. Graham, J. H., Gottwald, T. R., Cubero, J., and Achor, D. S. 2004 Xanthomonas axonopodis pv. citri: Factors affecting successful eradication of citrus canker. Mol. Plant Pathol. 5:1-15.

17. Grey, B. E., and Steck, T. R. 2001. The viable but nonculturable state of Ralstonia solanacearum may be involved in long-term survival and plant infection. Appl. Environ. Microbiol. 67:3866-3872.

18. Hartung, J. S., Daniel, J. F., and Pruvost, O. P. 1993. Detection of Xanthomonas campestris pv. citri by the polymerase chain reaction method. Appl. Environ. Microbiol. 59:1143-1148.

19. Hartung, J. S., Pruvost, O. P., Villemot, I., and Alvarez, A. 1996. Rapid and sensitive colorimetric detection of Xanthomonas axonopodis pv. citri by immunocapture and a nested-polymerase chain reaction assay. Phytopathology 86:95-101.

20. Hauben, L., Vauterin, L., Swings, J., and Moore, E. R. B. 1997. Comparison of 16S ribosomal DNA sequences of all Xanthomonas species. Int. J. Syst. Bacteriol. 47:328-335.

21. Heid, C. A., Stevens, J., Livak, K. J., and Williams, P. M. 1996. Real time quantitative PCR. Genome Res. 6:986-994.

22. Josephson, K. L., Gerba, C. P., and Pepper, I. L. 1993. Polymerase chain reaction detection of nonviable bacterial pathogens. Appl. Environ. Microbiol. 59:3513-3515.

23. Kutyavin, I. V., Afonina, I. A., Mills, A., Gorn, V. V., Lukhtanov, E. A., Belousov, E. S., Singer, M. J., Walburger, D. K., Lokhov, S. G., Gall, A. A., Dempcy, R., Reed, M. W., Meyer, R. B., and Hedgpeth, J. 2000. 3'Minor groove binder-DNA probes increase sequence specificity at PCR extension temperatures. Nucleic Acids Res. 28:655-661.

24. Livak, K. J., Flood, S. J. A., Marmaro, J., Giusti, W., and Deetz, K. 1995. Oligonucleotides with fluorescent dyes at opposite ends provide a quenched probe system useful for detecting PCR product and nucleic acid hybridization. PCR Methods Appl. 4:357-362.

25. Llop, P., Bonaterra, A., Penalver, J., and Lopez, M. M. 2000. Development of a highly sensitive nested-PCR procedure using a single closed tube for detection of Erwinia amylovora in asymptomatic plant material. Appl. Environ. Microbiol. 66:2071-2078.

26. Llop, P., Caruso, P., Cubero, J., Morente, C., and Lopez, M. M. 1999. A simple extraction procedure for efficient routine detection of pathogenic bacteria in plant material by polymerase chain reaction. J. Microbiol. Methods 37:23-31.

27. Louws, F., Rademaker, J., and de Bruijn, F. 1999. The three Ds of PCR based genomic analysis of phytobacteria: Diversity, detection, and disease diagnosis. Annu. Rev. Phytopathol. 37:81-125.

28. Mackay, I. M., Arden, K. E., and Nitsche, A. 2002. Real-time PCR in virology. Nucleic Acids Res. 30:1292-1305.

29. Manahan, S. H., and Steck, T. R. 1997. The viable but nonculturable state in Agrobacterium tumefaciens and Rhizobium meliloti. FEMS Microbiol. Ecol. 22:29-37.

30. Mavrodieva, V., Levy, L. , and Gabriel, D. W. 2004. Improved sampling methods for Real-Time polymerase chain reaction diagnosis of citrus canker from field samples. Phytopathology 94:61-68.

31. Mohammadi, M., Mirzaee, M. R., and Rahimian, H. 2001. Physiological and biochemical characteristics of Iranian strains of Xanthomonas axonopodis pv. citri, the causal agent of citrus bacterial canker disease. J. Phytopathol.-Phytopathol. Z. 149:65-75.

32. Moreira, L. M., Souza, R. F., Almeida, N. F., Setubal, J. C., Oliveira, M. C., Furlan, L. R., Ferro, J. A., and da Silva, A. C. R. 2004. Comparative genome analyses of citrus-associated bacteria. Annu. Rev. Phytopathol. 42:163-184.

33. Morrison, T. B., Weis, J. J., and Wittwer, C. T. 1998. Quantification of low copy transcripts by continuous SYBR (R) green I monitoring during amplification. Biotechniques 24:954.

34. Rasmussen, R. 2001. Quantification on the Light Cycler. Page 21-34 in: Rapid Cycle Real Time PCR: Methods and Applications. S. Meuer, C. Wittwer, and K. Nakagawara, eds. Springer Press, Heidelberg, Germany.

35. Sambrook, J., and Russell, D. W. 2001. Molecular Cloning. Cold Spring Harbor Laboratory, Cold Spring Harbor, NY.

36. Schubert, T. S., Rizvi, S. A., Sun, X. A., Gottwald, T. R., Graham, J. H., and Dixon, W. N. 2001. Meeting the challenge of eradicating citrus canker in Florida-again. Plant Dis. 85:340-356.

37. Sun, X., Stall, R. E., Cubero, J., Gottwald, T. R., Graham, J. H., Dixon, W. D., Schubert, M. E., Peacock, M. E., Dickstein, E. R., and Chaloux, P. H. 2000. Detection of a unique isolate of citrus canker bacterium from Key lime in Wellington and Lake Worth, Florida. Paper read at International Citrus Canker Research Workshop, Fort Pierce, FL. 
38. Sun, X. A., Stall, R. E., Jones, J. B., Cubero, J., Gottwald, T. R., Graham, J. H., Dixon, W. N., Schubert, T. S., Chaloux, P. H., Stromberg, V. K., Lacy, G. H., and Sutton, B. D. 2004. Detection and characterization of a new strain of citrus canker bacteria from key Mexican lime and Alemow in South Florida. Plant Dis. 88:1179-1188.

39. Swarup, S., Defeyter, R., Brlansky, R. H., and Gabriel, D. W. 1991. A pathogenicity locus from Xanthomonas citri enables strains from several pathovars of Xanthomonas campestris to elicit cankerlike lesions on citrus. Phytopathology 81:802-809.

40. Taggart, E. W., Byington, C. L., Hillyard, D. R., Robison, J. E., and Carroll, K. C. 1998. Enhancement of the AMPLICOR enterovirus PCR test with a coprecipitant. J. Clin. Microbiol. 36:3408-3409.

41. Verniere, C., Hartung, J. S., Pruvost, O. P., Civerolo, E. L., Alvarez, A. M., Maestri, P., and Luisetti, J. 1998. Characterization of phenotypically distinct strains of Xanthomonas axonopodis pv. citri from southwest Asia. Eur. J. Plant Pathol. 104:477-487.

42. Wilson, M., and Lindow, S. E. 1992. Relationship of total viable and culturable cells in epiphytic populations of Pseudomonas syringae. Appl. Environ. Microbiol. 58:3908-3913.

43. Yang, Y. N., and Gabriel, D. W. 1995. Xanthomonas avirulence/pathogenicity gene family encodes functional plant nuclear targeting signals. Mol. Plant-Microbe Interact. 8:627-631. 